\title{
Regulatory options for exchange, use and conservation of animal genetic resources: a closer look at property right issues ${ }^{1}$
}

\author{
M.W.Tvedt ${ }^{1}$, S.J. Hiemstra ${ }^{2}$, A.G. D rucker ${ }^{3}$, N. Louwaars ${ }^{2} \&$ J.K. 0 Idenbroek $^{2}$ \\ ${ }^{1}$ TheF ridtjof $\mathrm{N}$ ansen Institute, P. O . Box 1326, N-1326 Lysaker, N orway \\ ${ }^{2} \mathrm{C}$ entrefor $\mathrm{G}$ enetic Resources (CGN ), W ageningen U niversity and Research Centre, W ageningen, The $N$ etherlands \\ ${ }^{3}$ School for Environmental Research, Institute of A dvanced Studies, \\ Charles D arwin U niversity, Ellengow an D rive, N T 0909, A ustralia
}

\section{Summary}

Threemain areas for further development of policies or regulatory options for animal genetic resources (AnGR) wereidentified in astudy on theexchange, use and conservation of AnGR (Hiemstra et al., 2006):

1. how to halt thefurther erosion of genetic diversity and promotesustainablebreeding and use,

2. whether thereis a need to further regulatethe exchange of genetic material and

3 how to balance different systems of property and userights.

This paper provides an in-depth analysis regarding thethird challenge, that of addressing the problems and options available for balancing the different property right systems for A nGR.

\section{Résumé}

On a identifiétrois domaines principaux pour le développement futur depolitiques ou règlements pour les ressources génétiques animales (AnGR) dans une étude sur l'échange, I'utilisation et la conservation des A nGR (H iemstra et al., 2006):

1. Comment empécher l'érosion dela diversité génétiqueet promouvoir uneamélioration et utilisation durable.

2. Quand est-il nécessaire deréglementer les échanges dematériel génétique.
3. Comment harmoniser les différents systèmes de propriétéet droits.

Cer articleprésenteuneanalyse détailléedu troisième point, c'est à dire, comment approcher les problèmes et quelles sont les options disponibles pour harmoniser les différents systèmes de droits de propriétédansledomainedeAnGR.

\section{Resumen}

Sehan identificado tres áreas principales para futuros desarrollo de políticas o reglamentos para los recursos zoogenéticos (AnGR) en un estudio sobreel intercambio, la utilización y conservación deAnGR (Hiemstra et al., 2006):

1. Cómo impedir la erosión dela diversidad genética y promover una mejora y utilización sostenible.

2. Cúando es necesario reglamentar el intercambio dematerial genético.

3. Cómo harmonizar los distintos sistemas de propiedad y derechos.

Este artículo presenta un análisis detal lado del tercer punto, es decir, cómo enfocar los problemasy cuales son las opciones disponibles para harmonizar los distintos sistemas de derechos de propiedad en el campo deA nGR.

Keywords: AnGR, Regulatory options, Patent, Sui generis, B reeders' rights and livestock keepers' rights

\footnotetext{
${ }^{1}$ This paper summarizes the main findings on property right issues of a study by Himestra et al. (2006) entitled "Exchange, use and conservation of animal genetic resources: policy and regulatory options". The study was commissioned by FAO and funded by the Government of the United Kingdom of Great Britain and Northern Ireland, through DFID. The views expressed in the study and in this paper are the sole responsibility of the authors. The full report is downloadable from: www.cgn.wur.nl/U K/CGN +A nimal+G enetic+Resources/Policy+advice/ www.cgn.wur.nl/U K/CGN +General +Information/Publications/2006/ www.fao.org/ag/againfo/subjects/en/genetics/documents/ITW G-A nGR 4/A nGR_policy_and_regul.pdf
} 


\section{Introduction}

Theanalysis of different property right and legal systems (in this paper) forms part of a larger study by Hiemstra et al. (2006) into how exchange practices regarding AnGR affect thevarious stakeholders in thelivestock sector.

Thestudy's main objectivewas to identify policies and regulatory options for theglobal exchange, useand conservation of AnGR (Hiemstra et al., 2006 and Hiemstra et al., this issue). The background for FAO to commission this study was a recommendation from thel ntergovernmental Technical Working Group on A nimal Genetic Resources (see: CGRFA/ WG-A nGR-3/ 04/ REPORT, paragraph 24). The analysis of policy and regulatory options avai lable is based on literature surveys, scenarios analysis and stakeholder consultations (Hiemstra et al., 2006; Drucker et al., this AGRI issue).

Different legal systems and types of property rights are relevant to AnGR. The current legal framework shapes the freedom to use, breed and sell AnGR on national, regional and gl obal levels. For farm animals and thus al so for AnGR, private ownership is the ruleand public domain the exception. Theprincipal point of departureis that the owner of theindividual animal has the right to use the genetic resources in further breeding or even to sell genetic material (for a moreprofound discussion of ownership of AnGR, seeHiemstra et al. 2006, pp. 15-16; Tvedt et al. 2007, pp. 8-10).

Theright to use the animal in breeding is often specified in a (formal or informal) contract between theseller and thebuyer of theanimal. The contract or informal agreement determines thescope of what is transferred and which rights still belong to the seller (if any). Contracts imply a dynamic element in establishing (or transferring) rights from one owner to theother. The most important limitation of the use of a contact is that it only applies between two parties, and has limited legally binding effects for third parties(For a more detailed discussion of contracts, seeTvedt et al., 2007, p. 11-12).

Intellectual property rights are also used in the animal sector. Currently, themost familiar is a trademark. A trademark is a "sign, or any combination of signs, capable of distinguishing the goods or services" that may add valueto a product by distinguishing the product from other similar products in themarket(TRIPSArticle15).

Thus a trademark does not target the AnGR per se, but products developed from animals. Geographical indications can protect "indications which identify a good as originating in the territory of a
$M$ ember, or a region or locality in that territory, wherea given qual ity, reputation or other characteristic of the good is essentially attributable to its geographical origin" (TRIPS Article22, paragraph 1). Similar to trademarks, geographical indications do not protect the breed or genetic material per se, but may add commercial valueto theanimals or breeds produced in a particular region. A third type of intellectual property right which is relevant for AnGR are patents (seesection A below).

This paper addresses the problems of, and options availablefor, balancing different property right systems for AnGR. Threegroups of regulatory options can beidentified:

1. Patent law and animal breeding.

2. Sui generis protection in animal breeding.

3. Livestock keepers' rights.

Section A explains the current situation regarding patent law as applied to the animal breeding sector. Section B identifies possible sui generis systems, which could be (further) developed for AnGR. Section C elaborates further on thespecific issue of livestock keepers' rights (or farmer's rights). Finally in Section D wesummarize our main conclusions and highlight key issues to be discussed in international forums.

\section{Section A. Patent Law and Animal Breeding}

Patent law is general in scope, applying to all fields of technology and innovation [for a morein-depth analysis of how patent law applies to animal breeding and A nGR, seeTvedt (2007, forthcoming) and Nuffield Council on Bioethics (2001) regarding an analysis how patent law applies to genes in general ]. Consequently, it does not necessarily take into account the specific needs and challenges of AnGR or theanimal breeding sector (Tvedt 2007, Rothschild and Newman 2004 and Rothschild and Newman 2002). Themain legitimacy of this existing legal framework rests in its contribution to innovation, research and development. If patent law is not contributing to increased research and development in thisfield, thetime-limited monopolies can hardly bejustified. Oneconcern for AnGR is that a high number of claims, as is common for patent applications in the plant sector, may lead to theestablishment of a significant body of exclusiverights with substantial impact upon the use of AnGR by researchers, breeders and farmers. The potential consequences areyet to beseen. 
In the plant breeding sector, the main ruleis that Plant Genetic Resources (PGR) arein the public domain and open to use by everyone. This is quite different from the case of AnGR, which are often in individual or communal privateownership. It may well bethat theneed to maintain a viablepublic domain for AnGR is not as important as it is for plants (For an analysis of public domain for genetic resources in general, seeTvedt 2005). However, if patent protection is granted with a low requirement of inventiveness and novelty (potential examples arein fact in the process of being granted (see Fitzgerald 2005), and if granted broadly in terms of scope, research and breeding activities which were previously widely possiblemight becomemore restricted. In somecases this could even impact traditional uses in thecountry of origin. Dueto the short history of applying patents to AnGR, thereis an absence of case law and scholars commenting on how these general principles of law will beapplied in this particular area. In this context, this study has identified thefollowing questions that may raise particular problems in thefuture.

\section{Patentability in the animal sector}

Thequestion of what types of inventions areeligible for patent protection was previously left to the discretion of each country. This was radically altered by theA greement on Trade-Related Intellectual Property Rights(TRIPSA greement) under theWTO, which establishes a comprehensive scope of patentability by requiring all member countries to providefor patent protection in all fields of invention, savefor somenarrow exemptions: Countries areallowed to exempt patent protection of animals other than micro-organisms, and for essentially biological processes (TRIPS Agreement 27, paragraph 3).

TheTRIPSA greement essentially creates opportunities for exempting animals sother than micro-organisms from product patent protection in national patent law. The practical implications of this exemption depend upon theinterpretation of thelegal concept 'other than micro-organisms'. Thereis no definition or any agreed understanding of theterm 'micro-organisms' among the parties to theTRIPSA greement. Thus, countries have significant discretion as to whether to includeor excludeanimals, animal-proteins, genes and cells under patent protection in their national patent system, which may have a significant impact on biotechnology. Onelinguistically possible interpretation of this term is that countries havethe freedom to exempt product patent protection for every category of animal-related biological invention except those being clearly recognised as micro-organisms in a biological sense [Correa (2007, p. 293); Westerlund (2001) takes the opposite position and argues that the exemptions should be interpreted narrowly, seealso de Carvalho (2005)].

Consideration of the patent applications received under theWIPO Patent Cooperation Treaty system shows that process patents arehighly relevant for theanimal sector (Tvedt, 2007) and that countries are highly likely to grant process patents in thefield of animal breeding. The TRIPS article27 paragraph 3opens for countries to exempt "...essentially biological processes for the production of [... ] animals", but obliges countries to del imit such an exemption and providefor patents to "other than nonbiological and microbiological processes". The essential question is what is an "essentially biological process"? A WIPO official, deCarvalho, argues that this wording should "... be read in a restrictive manner...", since it is an exemption and maintains that: "...there are processes which are biological, to the extent they comprise some phasein which biological reproduction is employed, yet their most important steps consist of acts of human direct interference. These processes, in essence, are not biological" and must therefore, according to him, bepatentableaccording to his understanding of the TRIPS A greement (de Carval ho 2005, pp. 217-218). Correa notes that “...its main aim in the TRIPS A greement context is probably to limit the exclusion of patentability to traditional breeding methods [... ]" (Correa 2007, p. 293). N otethat neither of them are discussing this issue particularly within the context of theanimal breeding sector. AstheTRIPS agreement does not specify the legal concept further, countries havesomediscretion to implement a broad or narrow definition and practice of the concept of essentially biological processes for the production of animals. Theexperiencefrom theEU Directive on thelegal protection of biotechnological inventions (EC/ 98/44) shows that this discretion has in fact been used to implement a narrow exemption from patentability in Europe (Tvedt, 2007). Wemay therefore expect differences among countries with regards to thescope of patentability both for product and process patents, but as a general rule patent protection can be expected to becomewidely availablein thefield of animal breeding. 


\section{Prior art}

The concept of 'prior art' relates to what is considered to bea body of information which cannot be patented. In principle, everything al ready known should beconsidered part of prior art and thus ineligibleto meet the patent criteria. However, this is only a formal point of departure as the national patent officemust put this principleinto practice. For an activity wherethecurrent practices or prior art are not necessarily published in a sufficiently formal manner, thereis a concern that common knowledgecould conceivably become patent protected. To avoid such occurrences, measures could betaken to ensurethat all relevant sources be covered during the prior art search process. Such a measure could beimplemented by expanding the check-list for patent offices when they search for prior art.

Although preventivepublishing is often put forward as astrategy to ensure that common knowledgewill beconsidered prior art, it should be taken into consideration that such publishing only prevents patents from being granted in relation to that specific and particular form of published information. This means that preventivepublishing may proveto beless effectivein protecting against small adaptations to what was originally published. The largenumber of patent applications for different breeding methods which are currently being considered by patent offices is al ready increasing thechallenge of identifying relevant prior art.

\section{Novelty and inventiveness}

The novelty of an invention is considered by comparing the prior art with theinvention described in the patent claims. If thesetwo textual sources areidentical the novelty criterion is not met and the patent should not be granted. In technical areas whereextensive publication is not thenorm, the chance of meeting the novelty criterion is higher than for areas wherethereis an extensivebody of publications. Thelivestock sector might thus be exposed to many patent applications meeting the patent criterion even if they arenot particularly novel in a practical sense. Thesameitems of prior art are used to assess inventiveness. If a low level of inventiveness is required, a granted patent may include what was defacto al ready known or in practice. Practical measures to deal with these problems includethe development of specific guidelines for patent offices relating to how such assessments should beconducted. Such specific guidelines would of course haveto comply with the requirement in the TRIPSA greement, which states that patent protection is granted without discrimi nation among the various technological fields. Specific regulation of aspects of biotechnology patents is al ready accepted by theEU Directive on Biotechnological Patents (EC/ 98/ 44), so theTRIPSAgreement does not closethedoor to adapting special guidelines for single areas of invention. The general conclusion with regard to AnGR issues is thereforethat an important gap needs to beaddressed in order to ensure that methods al ready in existence do not become patented dueto a lack of formal publications.

\section{Scope of the granted right}

After a patent is granted, thenext task is to determinethescope of theexclusiveright that the claims would confer to the patentee. A ccording to theTRIPSA greement, Article28, thescope of a process patent protection is:

“... (b) wherethe subject matter of a patent is a process, [it confers a right] to prevent third parties not having the owner's consent from theact of using the process, and from theacts of: using, offering for sale, selling, or importing for these purposes at least the product obtained directly by that process."

The process patent covers an exclusiveright to theuseor application of the described method. But thescope of protection extends al so to cover at least the product obtained directly by that process. This means that the scope of process patent protection in theTRIPSA greement requires countries to provide for indirect product patent protection that covers the outcomefrom theuse of a patented method. Using a patented process might thereforegive the patenteea legal position in relation to the offspring from the application of the process. This is highly relevant for the breeding sector as thenext generations of animals bred by applying a patented method might becomesubject to the exclusiveright.

In addition to concerns regarding theabove principles and thegranting of patents, the application of the principle of equivalencemay createfurther difficulties when applied to livestock sector issues. Thescope of what is covered by a patent is described in the patent claims. While interpreting the written patent claims, in some countries thescope of patent protection is made 
even broader than it appears from a reading of the patent claims. Theinvention as described in the patent claims might beinterpreted to becomewider to also cover inventions that areso-called 'equivalent' to theinvention described in the patent claims. If such an expansive 'doctrine of equivalence' is applied, there is a possibility of restricting someoneelse's potential to carry out breeding and/ or research activities. Littleattention has been given to this principle in patent law and nonefor thearea of animal breeding. It is nevertheless an important issue, as it might become a significant factor in establishing broad exclusive rights. This will have unforeseeable consequences for AnGR. Since there hardly is any caselaw dealing with thesequestions in thelivestock sector, there is a need for athorough, systematic legal analysis related to assessing how general patent law rules will apply to AnGR and breeding (for further details, seeTvedt 2007).

\section{Exemptions to patent protection}

An additional measurefor supporting the adaptation of patent law could involvethe identification of useful exemptions that would lead to a more balanced application of patent law vis-à-vis thelivestock sector (for an analysis of the balancing of property rights in the aquatic sector, see Rosendal 2006). In this context, it is important to note that al though a patent grants the exclusive right to usean invention as it is described in the patent claim, Article 30 of theTRIPSA greement specifies that "countries have discretion to implement exemptions in theright conferred by the patent on a general level in the patent act". One example of such an exemption applies to plants in Europe, wheretheEU Patent DirectiveA rticle11 implements a version of the 'farmers' privilege' i.e. theright of thefarmer to reusehis harvest as seeds under certain specific conditions even if those seeds contain a patented gene. There is a similar opening for EU countriesto implement an exemption in theanimal sector according to the directiveand a widediscretion for all countries according to the TRIPSA greement. N evertheless, surprisingly few developing countries have implemented such legitimateexemptionsin their patent legislation.

Finally, it is also worth considering the degreeto which patent protection is needed in practise to promote breeding, research and development in this sector. While theissue of increased bureaucracy is often raised as a counter argument to the implementation of CBD-based access legislation, it should al so betaken into consideration that the patent application process and subsequent enforcement arealso time-consuming, expensive and heavily dependent upon theinvolvement of lawyers. It would therefore be useful to assess what thepotential benefits of patent protection might be for breeding, research and development in this sector, taking into account the fact that the investments of breeders and others need to be protected. This would need to beweighed against any potential costs, e.g. increased costs of breeding material and reduced exchangeand use of AnGR.

\section{Section B. Sui G eneris Protection in Animal Breeding}

Theterm 'sui generis' is not a clearly defined legal term or concept in international intellectual property law. The TRIPSA greement talksabout "an effectivesui generis system" for the protection of plant varieties as an alternativeto providing patent protection to the samesubject matter. But theTRIPS Agreement does not itself definesuch a system 'of its own kind' - a sui generis model for plant variety protection. Oneexample of such a sui gen eris system for the protection of plant varieties arethe plant breeders' rights under the different versions of the UPOV Convention. Sui generis systems for traditional knowledge haveal so been on the agenda at theWorld Intellectual Property Organisation (WIPO) for someyears, but agreement on such an international system is still far off. If a sui generis system for AnGR wereto bedeveloped, it is crucial that the differences between plants and animals are carefully taken into account.

For AnGR it is not immediately apparent which subject matter requires further intellectual property protection. Wheresuch a subject matter is identified and could beprotected within the context of a sui generis system, then there isstill a need to clarify inter alia i) who needs protection, ii) which entity should betheholder beneficiary to theright, iii) what should bethecriteria for achieving protection, and iv) what should beincluded under the exclusiveright. In thefollowing section four options for sui generis protection are discussed:

\section{A nimal variety or breed protection}

In considering the application of an intellectual property right such as a sui gener is system for 
AnGR or thebreeding sector, defining the precise subject matter that should be protected by theright is clearly important. Compared to plant variety protection, providing intellectual property protection for 'animal varieties/ breeds' would not makemuch sense dueto biological reasons. The variety/ breed is probably not themost relevant entity in animal breeding, but rather theindividual breeding animal or its germplasm. Furthermore, the concept of an animal variety/ breed is not easily defined. Such considerations mean that in terms of development of a sui generis system for thelivestock sector, it would be difficult to identify characteristics that could serve as a standard description of the 'subject matter'. Further work is required to clarify therelevant subject matter for protection.

\section{Establishment of breed associations}

A sui gen eris system could belinked to eligibility for being included in a particular register or herd book (managed by a breed association). Under such a sui generis protection system, registration would lead to the establishment of a right and the criteria for being granted that right are those required for being registered. The difficult question hereis what the rights (and legal consequences) conferred by such a registration should entail. For example, should such registration giveany exclusiverights to the genetic material? Onealternative could bethat registration gives rights to theindividual animal. However, such registration would not add much in addition to theal ready held physical property right over the animal plus the completegenome of the particular animal in question. A second alternative could be that registration of individual animals also confers an exclusive right to singlegenes or alleles in the registered animals. This alternativeis however problematic, as singlegenes or alleles often occur in a similar form in different individual animals and there is a need to avoid creating competing exclusiverights to the samegene. A third alternative could bethat only thosefarmers and breeders with animals registered by the breed association havethe right to use thename or brand of the breed. Such a 'sui generis protection' would be moresimilar to a regular trademark approach. Establishment of breed associations or herd book registration (governed by breeding laws) combined with trademark protection could therefore be a good option for breed conservation and property right protection.

\section{Rights to genetic material of individual animals}

Onemight al so think about establishment of a sui generis right to the genetic material of theindividual animal. With referenceto the second al ternative in the preceding paragraph, thefirst problem associated with such a right is the parallel occurrence of similar or identical genes and alleles in other animals. This would either underminethe exclusivity of such a right or result in competing property right claims. In addition to the problems related to identifying such genes, establishing a general sui generis right to thegenes of the individual animal would probably not add anything new compared to ownership of the animals.

\section{G eographical related properties}

A sui generis protection could al so belinked to special geographical related properties and characteristics of the animal s or their products (geographical indications). A final alternativefor a sui generis system would beto leaveit to the breeder to characterise in a sufficiently precise manner as to what s/ he claims as an exclusive right. This could then beused to establish a system for securing rights to technological developments and provide, for example, protection for a singlegenewhen isolated and described. Such protection is however al ready provided by theexisting patent system.

\section{Summing up options for sui generis systems}

To sum up, there are a number of relevant subject matters for intellectual property protection:

- At thelevel of theindividual animal - protection is conferred by physical ownership of that animal and/ or its offspring. Rights transferred during the purchase/ sale of individual animals can beprotected through theuse of contracts.

- At the breed level - protection through the establishment of breed associations (or herd books) and theuse of trademarks may be appropriate

- At theallelic, geneor protein level - protection is provided by patent law. 
- Technical inventions relevant for breeding - protection would becovered by current patent law.

The conclusion on sui generis intellectual property rights in theanimal sector is that it is not easy to identify the subject matter which needs to be protected. If a sui generis system wereto be developed therewould bea need for a more profound theoretical analysis in closecooperation with breeders to identify thesubject matter that needs further intellectual property protection. Such an analysis would also need to identify the necessity of stimulating breeding and innovativeness by using such a legal system.

\section{Section C. Livestock Keepers' Rights}

Livestock keepers' rights or farmers' rights to animals are unexplored legal or political concepts in thelivestock sector. Theterm 'farmers' rights' is mentioned in Article 9 of the ITPGRFA (FAO International Treaty on Plant Genetic Resources for Food and Agriculture). Farmers' rights 'recognize theenormous contribution' farmers havemade regarding plant genetic resources (PGR). Responsibility for realizing such rights rests with national governments and there is a clause specifying that Article 9 shall not limit any al ready existing 'rights that farmers have to save, use, exchange and sell farm-saved seed/ propagating material, subject to national law'. From a legal point of view, these 'rights' arenot formulated in a legally binding sense, which raises issues about their enforcement in practice.

Implementing a version of farmers' rights for livestock keepers (e.g. as formulated in such documentation as the 'Karen Declaration', which includes support for indigenous knowledge remaining in the public domain and that AnGR needs to beexcluded from IPR claims) would first requiresimilar international recognition of their crucial roleand contribution to AnGR.

Different strategies have been suggested for securing livestock keepers' rights, and theseinclude codifying the customary laws that relate to the management of AnGR. A first step in this direction would beto review and analyse relevant customary law in order to identify which principles need to be included. Given that grazing rights are crucial to maintai ning pastoral societies and are thus closely linked to conservation both at a breed level and at an all lic level, livestock keepers' rights could include production and grazing rights, as well as theprotection of traditional knowledge.

Mechanisms to strengthen livestock keepers' understanding of AnGR issues, their negotiating capacity and access to legal support would al so necessarily be a crucial element of a strategy for developing livestock keepers' rights.

Obstacles to theimplementation of livestock keepers' rights includethe fact that they could conflict with other intellectual property rights. For example, if a patent on a particular geneexisted, the consent of the patent holder could berequired when animals that express that genewere used for further breeding. Addressing this potential conflict is not however an insurmountable problem. For example, India has developed a Farmers' Rights law which carefully balances theserights for crop seeds. Similarly, wherelivestock keepers' rights could potentially conflict with other intellectual property rights, therewould bea need to haverules governing how theseinterests should betaken into account within the highly specified and enforceable body of patent law. Oneapproach would bethat livestock keepers' rights could inter al ia berelevant for inclusion both when assessment of the patent criteria is carried out, as well as during enforcement. However, sincelivestock keeper practises aretypically not published in a manner qualifying as prior art according to the patent system, this might expose them to patenting even if not new in a de facto sense. Two alternative approaches might also beconsidered:

1. either singlecountries could implement exemptions to intellectual property rightsfor livestock keepers; or

2. standard exemptions could bedeveloped at a regional or multilateral level.

It is also possibleto imaginesomeform of a sui generis protection system for livestock keepers' rights. This concept would haveto be developed further on a theoretical level, but could includea model for benefit sharing or could combine individual and community rights over A nGR. A crucial issue in the development of such a concept would be whether a sui generis system should includea positiveright to excludeothers or whether 
it should begeared towards being a negativeright aiming at preventing misappropriation of what is in use by livestock keepers.

\section{Section D. Conclusions: How to Balance the Rights of Stakeholders in the Livestock and Animal Breeding Sector}

'Classical ownership' of AnGR includes physical ownership and communal 'law of theland' affecting livestock keeping and breeding. The existing use of contract law in a more or less explicit manner is functioning rather well in thearea of animal breeding. Thereis, however, an increasing tension with developments in the realms of biodiversity law and intellectual property rights protection. Demarcation of thesedifferent rights systems and maintaining equity among different stakeholders is crucial to avoiding conflict and increased transaction costs. In this context, it is important to consider the rights of livestock keepers vis-à-vis national level sovereign rights, as well as obligations between patent holders and breeders/ livestock keepers. Balanceis not easily achieved as breeders have a need to protect their new investments as well thecurrent practices which are functioning and thus need not to be altered.

Thereareseveral potential options that could be explored in order to better balancetherights of different stakeholders in thelivestock sector under a range of futurescenarios. For examplespecific exemptions in patent law as applied to the animal sector could beimplemented. This is al ready a well-known strategy from in thecrop sector. Key issues related to the patent system al so could be considered and theseinclude: up-dating the prior art search practice, reviewing patent criteria for assessing potential innovations relating to AnGR, and/ or implementing exemptions for livestock keepers and breeders.

Sui generis protection options for AnGR could also beexplored, including through protection of breeds via the establishment of breed associations, defining livestock keepers' rights and assessing other strategies to secure investments. Notealso that sincelivestock keepers' rights are in an early phase of development as a legal concept, further development is likely to requiretheidentification of the needs of livestock keepers and how theseneeds can be addressed through the use of international policy or legal instruments.
The overall conclusion of this paper is that property rights need to beadequately adapted to the field of AnGR to beconducive to the exchange, conservation and sustainable use of AnGR. A second main observation is that for thesepurposes the balancing of property rights may not also be easily achieved. This is because breeders have a need to protect their new investments, whilecurrent practices are functional and thus do not need to be altered. Exploration of the options discussed in this paper may however assist in this task.

\section{List of References}

Correa, C.M . 2007. Trade Related A spects of Intellectual Property Rights: A Commentary on the TRIPSA greement, Oxford University Press, Oxford.

de Carvalho, N .P. 2005. The TRIPS Regime of Patent Rights, $2^{\text {nd }}$ edition. Kluwer Law International, TheH ague.

H iemstra, S.J., A .G . D rucker, M .W. Tvedt, N. Louwaars, J.K. O Idenbroek, K. A w gichew, S. A begaz Kebede, P.N . Bhat \& A . da Silva $M$ ariante. 2006. Exchange, Use and Conservation of A nimal Genetic Resources: Identification of Policy and Regulatory Options. CGN Report 2006/ 06. Centrefor Genetic Resources, Wageningen, The Netherlands.

N uffield Council on Bioethics. 2001. The Ethics of Patenting DNA. London: The Nuffield Foundation of Bioethics.

Rosendal, K .G ., I. O lesen, H .B. Bentsen, M.W. Tvedt, \& M. Bryde. 2006. A ccess to and legal protection of aquaculturegenetic resources: Norwegian perspectives, Journal of World Intel lectual Property 9, 392-412.

Rothschild, M .F. \& S. N ewman (Eds). 2002. Intellectual Property Rights in Animal Breeding and Genetics. New York: CABI Publishing

Rothschild, M .F., G. Plastow .\& S. Newman. 2004. Patenting in animal breeding and genetics, in A. Rosati et al. (Eds) WAAP Book of the Year 2003. Wageningen Pers, for World Association for A nimal Production (WAAP) 
Tvedt, M .W., S.J. H iemstra, A .G . D rucker, N . Louwaars \& K. O Idenbroek. 2007. Legal A spects of Exchange, Use and Conservation of Farm A nimal GeneticResources. FNI Report 1/ 2007. TheFridtjof Nansen Institute, Lysaker, N orway.

Tvedt, M .W. 2007 forthcoming. Patent protection in thefield of animal breeding and farm animal genetic resources, ACTA Scandinavia.

Tvedt, M .W. 2005. How will a substantive patent law treaty affect the public domain for genetic resources and biological material? Journal of World Intellectual Property 8, 311-344.
Tvedt M .W. 2007. 2005. Monsanto files for new invention: the pig, www.green peace.org/ international/news/monsanto-pig-patent-111\#.

Westerl und, L. 2001. Biotech PatentsEquivalency and Exclusions under European and U.S. Patent Law. Faculty of Law, Stockholm University, Stockholm, Sweden. 
